\title{
Crafting land restitution in Colombia: \\ Optimizing a legal, social and institutional framework
}

Jon D. Unruh

McGill University

\begin{abstract}
The dispossession of people from their land was a primary aspect of the war in Colombia. As an important part of the peace negotiations and current efforts at peace-building, land restitution in the country is a large-scale, multifaceted effort intended to address one of the more difficult components of the peace process. While there are many important features to the Colombian land restitution process, six stand out as particularly valuable, and therefore important for the international community to study for applicability elsewhere. These include, 1) involvement of affected communities in the derivation of the restitution program; 2 ) the construction of a database of land dispossession in the country; 3) the inclusion of gender considerations in the legal foundation for restitution; 4) constitutional protections for Afro-Colombian communities and indigenous peoples who are due restitution; 5) beginning the restitution process while the conflict is still underway; and 6) managing informality in land rights.
\end{abstract}

The Colombian peace process has been among the most challenging in the world. Land and territorial control was one of the central causes in the long conflict; and land dispossession continued during the war through the violent and fluid social context, arbitrary dispossession of rights, occupations and confiscations, and legal business, administrative and judicial processes. As a result land restitution issues were central to the peace negotiations, just as they are now a critically important part of the peace-building process in the country.

There are however ongoing challenges. There are security concerns in a number of areas, landmines must be removed and there are certain actors who are opposed to the restitution process -in some cases resulting in assaults on claimants, leaders and officials. In addition there is a reluctance among certain segments of the affected population to assert claims, and there is significant secondary occupation of land. In a land administration context there are incomplete and outdated land records and cadastre information, paper records at risk of destruction, and an institutional arrangement in the land sector that has created overlaps and gaps in competency and jurisdiction.

However the ambition, capacity and sense of purpose of the government and the Colombian people have demonstrated that even the most daunting peacemaking and peace-building challenges can be effectively pursued. The commitment of the government to land restitution provides an illustrative case where legal efforts, innovative use of technology, political will, and a recognition of the complexities as they exist on the ground, have been combined to address this fundamental component of the Colombian 
peace process. And while the contribution to peace and prosperity that land restitution will have in Colombia is important, the lessons learned from the Colombian experience have relevancy to the rest of the world-from states attempting to engage in peacebuilding, to international policy-makers and practitioners looking for effective best practices, and multi- and bilateral donors needing to know what and how to fund large-scale restitution programs. ${ }^{1}$

There have been many attempts across the globe in recent decades to find the right mix of political, institutional, legal, social, technological, and financial elements to address the complicated nature of war-affected land rights. What has made the Colombian experience notable? What lessons can be learned?

The story could begin in any number of places along the timeline of Colombia's 50 year war, but in a restitution context it really begins in 2011 with the passage of Law 1448, The Victims and Land Restitution Law. The following year the Land Restitution Unit (LRU) was created as part of this law. The LRU was given a daunting mandate-return displaced persons to their land from which they were dispossessed, provide and legalize their land titles, and support economic livelihoods once returns have occurred. The mandate involves processing as many as 160,000 land restitution cases and then present the claims to restitution judges to decide the cases; the decisions for which, are then to be implemented, all within a time frame of 10 years. This timeframe operates within international standards of 'transitional justice', in which specific legal and administrative procedures and institutions are put in place to mange the unusual circumstances of transitioning from the repercussions of armed conflict to peace. Transitional justice acknowledges that the laws, institutions and administrative procedures designed for peaceful, stable settings cannot adequately mange the problems that emerge from armed conflict.

Under Law 1448, people who were dispossessed from their land due to the the war can apply for restitution, or under certain circumstances compensation. Importantly the Law provides these forms of restitution both for families that possessed official title and for those that informally owned their land at the time of displacement and have no documents. Also included in the restitution program is support for rebuilding or acquiring houses for the displaced, regardless if they select to return to their original land or settle elsewhere.

In an unusual step found in very few other restitution laws in the world, informality in land rights was not avoided, but instead dealt with directly. The government correctly

This viewpoint is based on experience gained while working with the Colombian government's restitution efforts in 2007, 2012, and 2018. The current restitution program was compared to 12 other postwar land rights recovery programs the author has participated in, located Africa, Asia and the Middle East. In addition working documents and presentations from the Colombian Land Restitution Unit were reviewed, including URT (2018a; 2018b), FMC (2018) and Horta (2018); together with critiques of the current restitution program (e.g., Thomson 2017; Cortez 2013; Tenthoff and Eventon 2013); as well as the restitution law (RDC 2011). A preliminary version of version of this paper appeared in 'Land Restitution Unit Memoirs 2012-2018.' 
understood that much about war-affected displacement of populations involves a great deal of informality - lost, destroyed, stolen or fraudulent land records, lack of any records to begin with, and incomplete and poorly updated cadastre, registration and inheritance records. In addition there are problems that involve the records that do existforced sales of land, sales made under duress, and legitimate documents held by good faith buyers in transactions by bad faith sellers who confiscated land illegally. The Law recognizes these difficulties inherent to the processes of dispossession and restitution in war affected settings and provides for the use of a variety of alternative forms of evidence to support claims apart from simply the possession of the right document. This is done by way of innovative 'social cartography' mapping exercises regarding who owns what, and techniques for integrating informal tenure rights into the formal system (URT 2018).

This ability to manage informal rights and claims is a feature of the Colombian restitution program that the international community would do well to learn and understand because it is very much lacking in a number of other restitution processes; but yet fundamental to peace-building. In addition to this important feature, Law 1448 uses a set of presumptions and a reversal of the burden of proof to strengthen the inclusivity of the Law. The Law presumes that consent was not given in the transfer of land between the dispossessed person and anyone convicted of belonging to, collaborating with, or involved in financing illegal armed groups. The law also presumes a land transaction was not freely made when the amount paid was less than 50 percent of the real value of the land, unless strong evidence suggests otherwise. The same presumption applies when human rights violations, generalized violence, and mass forced displacement occurred in the surrounding area at the same time of dispossession. Such presumptions allows the burden of proof to be reversed in favour of the claimant, and as a result allows more claimants to participate in the restitution program, which is an important factor in peacebuilding and providing justice to the victims of the armed conflict.

These presumptions and conditions for establishing the burden of proof are important in dealing with secondary occupants (those that currently occupy land belonging to the dispossessed). In such cases secondary occupants and not claimants, must prove good faith possession of the land in question. In the absence of a good faith acquisition of land, the judicial decision is then made in favour of the claimant for restitution. And while ruling in favour of claimants then removes secondary occupants, this is not done without concern for justice regarding good faith secondary occupants who may not have sufficient proof of their good faith status. In such cases - so as to avoid creating an additional aggrieved group among displaced secondary occupants - the legal procedures allow for a socioeconomic characterization of the evicted secondary occupant to determine their livelihood vulnerability. Such vulnerability can then lead to compensation or other socioeconomic support. This concern for justice for vulnerable secondary occupants then contributes to the overall peace-building effort.

The new law does not operate in isolation. Rather it is part of a three-component policy design also comprising institutional reform and a set of special administrative procedures. The institutional component comprises the LRU and Land Restitution Courts and 
prioritizes certain areas of the country for immediate attention, and then moves to other areas. There are several advantages to this prioritization. First, it allows the restitution process to move much more quickly and effectively than would be possible if all affected areas over the entire country were dealt with all at once, which would spread the effort too thinly over large areas. The prioritization approach also allows for certain problematic areas to be dealt with first, such as high density affected areas, or areas where neglect would be costly or result in violence. Also prioritized are areas where security conditions allow for the return of dislocated families. This approach allows for restitution efforts to operate in a concentrated way, and thus be noticed quickly by local communities and other affected persons. This is important in a justice context because not only must justice be served, but it must be seen by the affected population to be served. In other words the more the restitution effort is noticed, the more the affected population will perceive that justice is being served-which is very important to overall peace-building.

The Special Procedures component of the policy design comprises a set of mixed or hybrid processes that combine elements of the law, courts, and the LRU. The role of such hybridized special procedures in a peace-building context is important, because these are then able to attend to specific realities as they exist on-the-ground, which may not fit into existing legal structures or procedures. Special procedures are also able to move quicker to respond to certain difficult situations. Not having such a set of special procedures would mean that those within the affected population who have a variety of unusual circumstances would not be attended to, thus jeopardizing the notion of justice for a segment of victims of dispossession.

The overall policy is implemented by way of a set of land restitution procedures through which applications for restitution pass. The procedures are comprised of an administrative phase, a judicial phase and the post-ruling phase. The administrative phase entails an administrative review of the application to verify that claimants are in fact eligible for the restitution program. This is accomplished by officers visiting communities so as to reconstruct the history of ownership for the property. Such reconstruction is a very effective way to deal with properties whose dispossessed owners do not have official documentation-thereby including these owners in the restitution process. The land tenure history then serves as evidence for eligibility in the restitution program. Once eligibility is established, the judicial phase then moves the case to a special judge who determines if the land in question should be returned to the claimant. The post-sentence phase then has the LRU assisting returning families to rebuild their livelihoods with training and financial support. To date the government has spent over $\$ 60$ billion pesos (2.2 million US dollars) on important projects that support livelihoods. The LRU also helps victims to document their case for submission for judicial review at no cost. Having the application process be free is another way to include as many people as possible in the restitution process.

While there are many important features to the Colombian restitution process, six stand out as particularly valuable, and therefore important for the international community to study for applicability elsewhere. First, throughout the process of deriving and implementing the restitution program, there was significant community involvement, thus en- 
suring a good fit between the program and the needs and challenges of dispossessed communities. Community involvement is an important step in peace-building because it provides for a sense of belonging and ownership by the affected communities, and allows for the program to become aware of problems it might otherwise not know about. It also provides a strong signal that government is serious about restitution. Second, one of the outcomes of the restitution effort has been the consolidation of the only database of land dispossession in the country, complete with geo-referenced information. Such a database is an important technical peace-building tool that facilitates tracking, organizing and categorizing claimants. Third is the gender aspect of land rights and restitution. In rural Colombia a significantly low percentage of women are owners of land. This is a significant problem for women head of households who are attempting to return to their land. Under the restitution program, an awareness raising campaign is launched to advocate that women are legal land rights holders, such rights are not derived from a husband's rights, and that joint ownership involving a husband and wife is allowed for property registration and titling. A fourth component involves the Afro-Colombian communities and indigenous peoples who are due restitution. This involves constitutional protections and includes special measures designed specifically for these communities. These measures involve traditional authorities to help deal with the de facto dispossession that took place during the conflict as well as such problems as the presence of illegal crops, mining, deforestation and other illicit activities. Fifth, is the fact that the restitution process was initiated while the armed conflict was still underway. This is important because it demonstrates the value of getting a head-start on the land restitution processincluding preparation of the legal, technical, institutional, societal and financial aspects - before the war is over, thereby facilitating a much quicker, more effective and lower cost process. It can be argued that beginning such a restitution process prior to the end of the war can even influence the conduct of the war itself; by potentially acting to prevent further dislocations in some areas, and serving as a warning to those that seek to dispossess people that they will not likely ultimately succeed. This can also provide a warning to those who may seek to purchase such land that they will likely lose them, and also lose the money they paid for such land. This is an important lesson for the international community, and opens the door to a number of possibilities in terms of peace-making and peace-building. And finally the sixth feature is the important role of managing informality in land rights that was noted previously.

The implementation of the law and policy is now underway, and to date approximately 220,000 hectares have been restored benefitting over 30,000 people. Most families that have successfully had their land returned to them (84 percent) are now living or working on the farms.

Today Colombia stands as a model for other countries and international organizations struggling with the complexities of land restitution and its important role in peace-building. Finding the right techniques, technologies, institutions and laws needed to effectively implement a land restitution process so as to deliver justice to victims of armed conflict has perplexed academics, policy-makers and practitioners concerned with peacemaking and peace-building; and the contribution Colombia has made is quite significant. The country demonstrates that with the right mix of political will, legal capacity, flexibility, 
and awareness of the realities on the ground, land restitution can contribute very substantially to the country's overall peace-building objectives. Land restitution efforts in Honduras, Nepal, Kenya and Sri Lanka are examining the Colombian experience as they move to established their own programs, and this author has used the Colombian case in work on Iraq and Syria. In addition, United Nations agencies have recognized the contribution Colombia has made to deriving and implementing effective approaches to land restitution; and members of the LRU are called upon internationally to share their experience of engaging with one of the more important global issues of our time.

While there are obstacles to overcome, the Colombian land restitution program has built impressive momentum. This technical, legal, social and institutional momentum is a difficult thing to put together-and it is hoped that the new government of the country is supportive of its effective implementation.

\section{References}

Unidad de restitucion de tierras (URT) (2018a) Memorias de la restitucion de Tierras. Unidad de Restitucion de Tierras, Bogotá.

Unidad de restitucion de tierras (URT) (2018b) Hellas y Rostropovich de la restitucion de tierras y territorios. Unidad de Restitucion de Tierras, Bogotá.

Fuerzas Militares de Colombia (FMC) (2018) Pedagogia sobre los roles y funciones de las FF.MM. en el processo de restitucion de tierras Ley 1448 de 2011. Fuerzas Militares de Colombia, Bogotá.

Horta, IM (2018) Land restitution policy: Colombia case study. Presented at the Sri Lanka reparations conference, February 2018, the World Bank.

Thomson F (2017) Land restitution in Colombia: why so few applications? FMR 56, available at: www.fmreview.org/latinamerica-caribbean

Cortez P (2013) The victims and land restitution law in Colombia in context. Transnational Institute, Amsterdam.

Tenthoff $M$ and Eventon R (2013) A vertitable revolution: the land restitution law and the transformation of rural Colombia. TNI Agrarian Justice Programme, Transnational Institute. 